\title{
THE ACQUISITI ON OF WORDS BY TWO-YEAR-OLD TWIN CHILDREN
}

\author{
Rosmita Ambarita \\ Fakultas Keguruan Ilmu Pendidikan Universitas Muslim Nusantara \\ Al Washliyah Medan
}

\begin{abstract}
This research was conducted to discover the acquisition of words acquired by two-yearold twin children, two females and two males. The two females were Yaya and Tata and the two males were Randy and Rendy. The main objectives of this research are to discover how the number words acquired by two-year-old twin children, to discover who acquires more verbs and nouns among the four subjects and to discover the differences between female and male twin children in acquiring words. The instruments used for data collection were observations and interviews. The observations were conducted for three months, twice a week and interviewing children's parents by asking some questions. The problems of this research were how many verbs and nouns are acquired by two-year-old twin children? Who acquires more words among the four twin children? Is there any difference between female and male twin children in acquiring verbs and nouns? Based on the observations, female children acquired more words than male children, but the male children produced the words clearer than female. Within that period, Yaya obtained 206 words, (134 nouns and 72 verbs), Tata obtained 237 words, (149 nouns and 88 verbs), Randy obtained 227 words, (136 nouns and 79 verbs), Rendy obtained 230 words, (138 nouns and 92 verbs). From all the words which were obtained by the subjects the result showed that nouns dominate the acquisition and the result of the observation Tata was the best in acquiring verbs and nouns among the four subjects.
\end{abstract}

Keywords : the acquisition of words, twin children

\section{INTRODUCTION}

\subsection{Background}

Language is uniquely human gift of evolution. It is subtle, abstract, and cultural phenomenon that no doubt come in the human biological system at a relatively later date. One of the remarkable characteristics of human beings is that every single one acquires language at a very young age. And later on the acquisition occurs and develops in its social context. The study of language acquisition potentially can tell us a great deal about the psychological and intellectual functioning of the children as they mature. The use of language is considered to have a tremendous affect on the children's relationship with themselves and the environment.

Babies are not born talking. They learn language immediately from birth. They hear sounds and words, meaning and constructions. They need to know what to use, where and when, how to integrate language with other modes of communication, how to make them understood and how to understand others. During the infants or very early childhood period, children learn to express things by using speech sounds. Whenever they feel hungry, thirsty or hurt, they produce speech sounds such as crying, which is also a part of the process of communication, where the infants start to use their articulation to 
communicate with other people because they are still not able to say perfectly what they want like adults do.

Language acquisition happens when conversation occurs in the environment or between the children and the adults. Speaking to children needs a special way in order to make the conversation happens. How adults talk to children also has certain incidental consequences because children are presented with special tailored model of language use and adjusted to fit as far as possible what they appear to understand.

Human beings are born to speak, with an innate gift for figuring out the rules of the language used in the environment. Environment influences the children in the conversation. Infants need other people such as their care takers, parents and the people around them to motivate them to communicate through crying, cooing, uttering sounds or meaningful words which help them to be able to carry out conversations, and to communicate their needs and wants with other people in the community. Sudjono Dardjowidjojo (2000:49) explains that the adjustment in the caretakers speech register served two functions, namely to facilitate understanding and to get the child to be involved in the conversation.

Clark (2003:12) mentions that the first language acquisition requires a comprehensive look at where and when children acquired the language. It integrates social and cognitive approaches on how children analyze, understand, and produce sounds, words and sentences as they learn to use the language to cooperate and achieve goals.
The adults influence the development of the children's language. The children carefully follow the movements of the mother's mouth and try to imitate them. They distinguish voice and showing a particular preference. They are sensitive to the rhythm and intonation of adults talk (de Boysson-bardies, 1999:37). Parents provide predictable repeated situations in which meaning of utterances is clear to the child. And they effectively teach their ideas over to the children. The children never make conversation with other people seriously, but they acquire the language and share the knowledge with other people.

One of the requirements in the process of studying a child's language acquisition is to understand the child's family background. It is an important fact to be studied so that the development can be well understood and will give a great deal of contribution to the process of a child's mental development.

The process of acquiring a language is regarded as very complex and interesting to be studied. The writer is very much interested in conducting a research on two twin children. She is very curious to observe the acquisition of words specifically the acquisition of verbs and nouns, and to discover whether the two twin children differ in the terms of the total number of verbs and nouns.

\subsection{Problems of the study}

1. How many words are acquired by two-year-old twin children?

2. Who acquires more words among the four twin children? 
3. Is there any difference between female and male twin children in acquiring words?

\section{METHOD}

This study was conducted by applying a qualitative research design. The problems stated in the research were about the acquisition of words by a- two- year- old twin children. It is a qualitative design because the writer observed the twoyear- old twin children in acquiring words, and it is a case study. A case study is a research that aims at analyzing a phenomenon in its real life context.

to guide and support the construction of hypothesis. Lincoln (1985:104) asserts that new participants are added as new dimensions of the issues and become apparent through earlier interviews.

In this study, it is a cross sectional research where the researcher chose four children of two twins, i.e. two males and two females. The observations were conducted for a period of three months. Recording technique was used to obtain the data. It was done without any conditioning within certain signs. It was conducted naturally and without controlling or manipulating in the arrangement of the conversations between the subjects and the environments. The words produced by the subjects of the research were recorded. The results of the recordings were analyzed. Library research was also employed for obtaining comprehensive data. In the library research, the information was collected on the basis of studying the references. In collecting the data, the subjects were observed directly by the researcher.
The subjects of the study were twin children of two years of age. They were two females and two males.

The data of this research were collected by two sources, they are:

\section{Interview}

In this research, the researcher prepared some interview questions to ask the subjects' parents. Morgan (1988:98) says an interview is a purposeful conversation, usually between two people, but sometimes more, in order to set information from the other. The researcher had carried out an indepth interview, by asking same questions to the children's parents

\section{Observation}

After completing the data collections, some steps were taken in analyzing the data:

1. Make a list of words produced by the children based on the alphabetical order.

2. Note the differences between the two female children in acquiring verbs and nouns.

3. Note the differences between the two male children in acquiring verbs and nouns

4. Make a list of the differences of the words acquired by the female and male children.

Finally, the data were analyzed to discover why those above acquired by the subjects.

\section{FINDINGS AND DISCUSSIONS}

The obtained data show a sufficiently significant development of a child on language acquisition by two-year-old twin children particularly in acquiring verbs and nouns. However, the findings show that there were some differences in 
language production or speech produced by the subjects of the same age. The results of the observations showed that Tata was able to produce and acquire words more than Yaya. Rendy acquired the words fewer than Randy, but for the pronunciation Rendy was better than Randy. Tata was acquired the most verbs and nouns among the four subjects. She was the best in acquiring verbs and nouns among them but Rendy was the best in pronunciation.

The researcher's curiosity and wonder on the process of acquiring words (verbs and nouns) by two-year-old twin children had been answered. The researcher realizes that this happened only to the subjects under this research. The fact might be different if the subjects are at different ages and different environments. Generalized to other twin children in terms of language acquisition that influenced by other factors such as parents' educational background and environment should be considred. Hopefully, other researchers who are interested in language acquisition will conduct other researches on this area.

\section{CONLUSSIONS}

As the last part of this research, the researcher presents some conclusions related to the findings. Based on the observations the researcher concludes that, the female twin children were acquired more words than the male at the same age.Yaya obtained 206 words (134 nouns and 72 verbs), Tata obtained 237 words (149 nouns and 88 verbs) Randy obtained 227 words (136 nouns and 79 verbs) and Rendy obtained 230 words (138 nouns and 89 verbs) but, the male produced the words clearer than female. Based on the observations, it can concluded that it could happen because of the influence of the environment, where the female twin children had a caretaker and two house keepers who lived with the female children, but the male children were taken care and raised by their mother.

From all the words, which were produced by the subjects, the results of the parts of speech showed that nouns dominate the words acquisition as the following.:

\begin{tabular}{|c|c|c|c|}
\hline No. & Meanings & Words & Parts of Speech \\
\hline 1 & Abang (brother) & abang/ $\Lambda \mathrm{b} \Lambda \mathrm{y} /($ Nov) & Noun \\
\hline 2 & Abu (dust) & $\mathrm{abu} / \Lambda \mathrm{bu} /(\mathrm{Jan})$ & Noun \\
\hline 3 & Ada (exist) & ada/ $\Lambda \mathrm{d} \Lambda /(\operatorname{Jan})$ & Verb \\
\hline 4 & Adek (sister) & 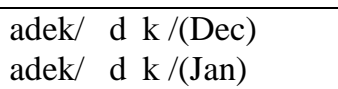 & Noun \\
\hline 5 & Air (water) & ai/ムi/(Nov) & Noun \\
\hline 6 & Aku (I) & atu/ $/ \mathrm{tu} /(\mathrm{Jan})$ & Noun \\
\hline 7 & Alis (eye brow) & 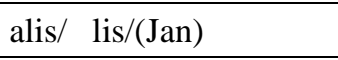 & Noun \\
\hline 8 & Amat (name of her friend) & amat/ $\Lambda \mathrm{m} \Lambda \mathrm{t} /(\mathrm{Jan})$ & Noun \\
\hline 9 & Ambal & $\mathrm{amban} / \Lambda \mathrm{mb} \Lambda \mathrm{n} /(\mathrm{Dec})$ & Noun \\
\hline 10 & Ambil (take) & $\begin{array}{l}\mathrm{mbe} / \mathrm{mb} /(\text { Nov) } \\
\mathrm{ambil} / \Lambda \mathrm{mbil} /(\operatorname{Jan})\end{array}$ & Verb \\
\hline 11 & Angkat (take up) & 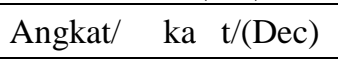 & Verb \\
\hline
\end{tabular}




\begin{tabular}{|c|c|c|c|}
\hline 12 & Anjing (Dog) & $\begin{array}{l}\text { gunggung } \\
\text { /gunggung/gunguy/ } \\
\text { gunguy/(Nov) gunggung/ } \\
\text { guyguy/(Nov) } \\
\text { andin//ndin/(Jan) }\end{array}$ & Noun \\
\hline 13 & Apel (apple ) & 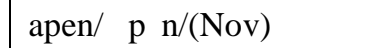 & Noun \\
\hline 14 & Api (fire) & api/ $/$ pi/(Jan) & Noun \\
\hline 15 & Asap (smoke) & $\operatorname{asap} / \Lambda \mathrm{s} \Lambda \mathrm{p} /(\mathrm{Jan})$ & Noun \\
\hline 16 & Atok (grandfather ) & tok/tck/(Nov) & Noun \\
\hline 17 & Ayah (father) & aya/ $/ \mathrm{y} \Lambda /(\mathrm{Nov})$ & Noun \\
\hline 18 & Ayam (Chiken ) & $\begin{array}{l}\text { elas / las/(Nov), } \\
\text { ayam/ } / \mathrm{y} \Lambda \mathrm{m} /(\mathrm{Nov})\end{array}$ & Noun \\
\hline 19 & Ayok (come on) & 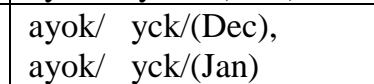 & Verb \\
\hline 20 & Ayun (swing) & ayun/ $\Lambda$ yun/(Dec) & Verb \\
\hline 21 & Baca (read) & $\begin{array}{l}\text { aca/ } / \mathrm{c} \Lambda /(\mathrm{Nov}) \\
\mathrm{baca} / \mathrm{b} \Lambda \mathrm{c} \Lambda /(\mathrm{Dec})\end{array}$ & Verb \\
\hline 22 & Baju (shirt) & aju/ad3u/(Nov) & Noun \\
\hline 23 & Baker ( & bakar/b $\Lambda \mathrm{k} \Lambda \mathrm{r} /(\mathrm{Dec})$ & Verb \\
\hline 24 & Bambu (bamboo) & $\mathrm{ambu} / \Lambda \mathrm{mbu} /(\mathrm{Dec})$ & Noun \\
\hline 25 & Bangku (chair) & angku/ $\Lambda \eta k u /($ Nov) & Noun \\
\hline 26 & Banting (fly away) & banting/b $\Lambda$ ntip/(Dec) & Verb \\
\hline 27 & Barat (west) & balat/b $\Lambda 1 \Lambda \mathrm{t} /(\mathrm{Dec})$ & Noun \\
\hline 28 & Batu (stone) & $\begin{array}{l}\mathrm{batu} / \mathrm{b} \Lambda \mathrm{tu} /(\mathrm{Dec}) \\
\mathrm{batu} / \mathrm{b} \Lambda \mathrm{tu} /(\mathrm{Dec})\end{array}$ & Noun \\
\hline 29 & Batuk (cough) & batuk/b $\Lambda$ tuk/(Dec) & Verb \\
\hline 30 & Bebek (duck ) & bebek/b b k/(Nov) & Noun \\
\hline 31 & Becak (pedicab) & ecak/ c $\Lambda \mathrm{k} /(\mathrm{Nov})$ & Noun \\
\hline 32 & Bedak (powder) & bedak/b d $\Lambda \mathrm{k} /(\mathrm{Dec})$ & Noun \\
\hline
\end{tabular}

\begin{tabular}{|c|c|c|c|}
\hline No. & Meanings & Words & Parts of Speech \\
\hline 33 & Belajar (study) & 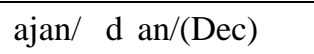 & Noun \\
\hline 34 & Beli (buy) & $\begin{array}{l}\text { beli/b li/(Dec) } \\
\text { beli/b li/(Jan) }\end{array}$ & Verb \\
\hline 35 & Beras (rice) & belas/b la $\Lambda$ s/(Dec) & Noun \\
\hline 36 & Bikin (make) & Bitin/bitin/(Jan) & Verb \\
\hline 37 & Bilang (say) & 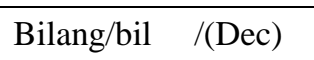 & Verb \\
\hline 38 & Bintang (star) & bintang/bint $\Lambda \mathrm{y} /(\operatorname{Jan})$ & Noun \\
\hline 39 & Bisa (bisa) & $\begin{array}{l}\text { ica/ic } \Lambda /(\text { Nov }) \\
\text { bica/bic } \Lambda /(\text { Dec }) \\
\text { bisa/bis } \Lambda /(\text { Jan }) \\
\end{array}$ & Verb \\
\hline 40 & Bonbon (candy) & bobon/bcbcn/(Jan) & Noun \\
\hline 41 & Boneka (doll ) & Uka/uk $\Lambda /(\mathrm{Nov})$ & Noun \\
\hline 42 & Botol (bottle) & oton/ctcn/(dec) & Noun \\
\hline 43 & Buah (fruit) & $\begin{array}{l}\text { buah/bu } \Lambda \mathrm{h} /(\text { Nov) } \\
\text { buah/ bu } \Lambda \mathrm{h} /(\mathrm{Nov})\end{array}$ & Noun \\
\hline 44 & Buang (throw) & buang/bu $\Lambda \mathrm{y} /(\mathrm{Dec})$ & Verb \\
\hline 45 & Buka (open) & kukak/kuk $\Lambda$ k/(Dec) & Verb \\
\hline
\end{tabular}




\begin{tabular}{|c|c|c|c|}
\hline & & buka/buk $\Lambda /(\operatorname{Jan})$ & \\
\hline 46 & Buku (book) & Uku/uku/(Nov) & Noun \\
\hline 47 & Bulek (aunty) & bulek/bul k/(Jan) & Noun \\
\hline 48 & Bunga (flower) & bunga/buy $\Lambda /($ Jan $)$ & Noun \\
\hline 49 & Bungkus (wrap) & bungkus/buykus/(Jan) & Verb \\
\hline 50 & Bunyi (sounds) & unyi/unyi/(Jan) & Noun \\
\hline 51 & Burung (bird) & bulung/lulun/(Jan) & Noun \\
\hline 52 & Buya (father) & buya/buy $\Lambda /(\operatorname{Jan})$ & Noun \\
\hline 53 & Cangkir (cup) & cangkin/cankin/(Dec) & Noun \\
\hline 54 & Cangkul (hoe) & Cakung/cakun/(Dec) & Noun \\
\hline 55 & Cari (find out) & Cali/c $\Lambda$ li/(Dec) & Verb \\
\hline 56 & Cebok (wash bottom ) & Ebok/ bck/(Nov) & Verb \\
\hline 57 & Celana (trousers) & ana/ $/ \mathrm{n} \Lambda /(\mathrm{Nov})$ & Noun \\
\hline 58 & $\begin{array}{lll}\begin{array}{l}\text { Cepek } \\
\text { rupiahs) }\end{array} & \text { (one hundred } \\
\end{array}$ & Tepek/t p k/(Dec) & Noun \\
\hline 59 & Cet (paint) & cet $/ c t /(\operatorname{Dec})$ & Noun \\
\hline 60 & Chitato (snack) & Titato/tit $\Lambda \mathrm{tc} /(\mathrm{Dec})$ & Noun \\
\hline 61 & Cium (kiss) & Ium/ium/(Jan) & Verb \\
\hline 62 & Coklat (chocolate ) & Okat/ck $\Lambda \mathrm{t} /($ Nov) & Noun \\
\hline 63 & Coret (scratch) & colet/ccl t/(Dec) & Verb \\
\hline 64 & Cubit & $\mathrm{bit} / \mathrm{bit} /(\mathrm{Dec})$ & Verb \\
\hline 65 & Cuci (wash) & cuci/cuci/(Jan) & Verb \\
\hline 66 & Datang (come) & datang $/ \mathrm{d} \Lambda \mathrm{t} \Lambda \mathrm{y} /(\operatorname{Jan})$ & Verb \\
\hline 67 & Dinding (wall) & diding/didin/(Dec) & Noun \\
\hline
\end{tabular}

\begin{tabular}{|c|c|c|c|}
\hline No. & Meanings & Words & Parts of Speech \\
\hline 68 & Do'a(pray) & $\mathrm{Doa} / \mathrm{dc} \Lambda /(\mathrm{Dec})$ & Verb \\
\hline 69 & Dompet (wallet) & ompet/cmp t/(Dec) & Noun \\
\hline 70 & Drum (drum) & Dlum/dlum/(Dec) & Noun \\
\hline 71 & Dua (two) & Dua/du $\Lambda /($ Jan $)$ & Noun \\
\hline 72 & Duduk (sit down ) & Dodok/dcdck/(Nov) & Verb \\
\hline 73 & Duduk (sit) & Duduk/duduk/(Dec) & Verb \\
\hline 74 & Duit (money) & $\begin{array}{l}\text { duit/duit/(Dec), } \\
\text { duit/duit/(Jan) }\end{array}$ & Noun \\
\hline 75 & Filim (film) & Pilim/pilim/(Dec) & Noun \\
\hline 76 & Gambar (drawing) & gamban/g $\Lambda \mathrm{mb} \Lambda \mathrm{n} /(\operatorname{Dec})$ & Verb \\
\hline 77 & Garuk (scratch) & Galok/g $\Lambda$ lck/(Dec) & Verb \\
\hline 78 & Gas (gas) & Gas/g $\Lambda \mathrm{s} /(\mathrm{Jan})$ & Noun \\
\hline 79 & Gayung (water dipper) & gayung/g $\Lambda$ yuy/(Jan) & Noun \\
\hline 80 & Gelang (bracelet) & gelang/g $1 \Lambda \mathrm{y} /(\mathrm{Jan})$ & Noun \\
\hline 81 & Gelas (glass ) & elas/ la $\Lambda \mathrm{s} /(\mathrm{Nov})$ & Noun \\
\hline 82 & Gigi (teeth ) & Gigi/gigi/(Nov) & Noun \\
\hline 83 & Gorden (curtain & oden/cd n/(Jan) & Noun \\
\hline 84 & Gula (sugar) & Gula/gul $\Lambda /($ Dec $)$ & Noun \\
\hline
\end{tabular}




\begin{tabular}{|c|c|c|c|}
\hline 85 & Guru (teacher) & Guyu/guyu/(Jan) & Noun \\
\hline 86 & Hand body (body lotion) & Body/bcdy/(Dec) & Noun \\
\hline 87 & Handuk (towel) & Andok/Andck/(Nov) & Noun \\
\hline 88 & Hantu (gost) & Antu/ $\Lambda$ ntu/(Jan) & Noun \\
\hline 89 & Hidung (nose) & $\begin{array}{l}\text { Idung/iduy/(Dec) } \\
\text { hidung/hiduy/(Jan) }\end{array}$ & Noun \\
\hline 90 & Huruf (alphabet) & Hulup/hulup/(Dec) & Noun \\
\hline 91 & Ikan (fish) & Ika/ik $\Lambda /($ Nov $)$ & Noun \\
\hline 92 & Ikut (come with) & Ikut/ikut/Jan) & Verb \\
\hline 93 & Jajan (buy) & $\mathrm{jaja} / \mathrm{j} \Lambda \mathrm{j} \Lambda /($ Nov $)$ & Verb \\
\hline 94 & Jatuh (fall down ) & $\begin{array}{l}\text { bam/b } \Lambda \mathrm{m} /(\text { Nov) } \\
\text { jatuh/d3 } 1 \text { tuh/(Dec) }\end{array}$ & Noun \\
\hline 95 & Kaca (mirror) & $\mathrm{aca} / \Lambda \mathrm{c} \Lambda /(\mathrm{Nov})$ & Noun \\
\hline 96 & Kaki (foot) & Aki/ $\Lambda \mathrm{ki} /($ Nov) & Noun \\
\hline 97 & Kancing (cotton) & Kancin/k $\Lambda$ ncin/(Jan) & Noun \\
\hline 98 & Kasih (give) & Kasi/k $\Lambda$ si/(Dec) & Verb \\
\hline 99 & Kau (you) & $\begin{array}{l}\operatorname{tau} / \mathrm{t} \Lambda \mathrm{u} /(\mathrm{Dec}) \\
\operatorname{tau} / \mathrm{t} \Lambda \mathrm{u} /(\operatorname{Jan})\end{array}$ & Noun \\
\hline 100 & Kawan (friend) & kawan $/ \mathrm{k} \Lambda \mathrm{w} \Lambda \mathrm{n} /(\operatorname{Dec})$ & Noun \\
\hline 101 & Kayu (wood) & $\mathrm{Kayu} / \mathrm{k} \Lambda \mathrm{yu} /(\mathrm{Dec})$ & Noun \\
\hline 102 & Kecap (ketchup) & $\begin{array}{l}\text { ecap/ c } \Lambda \mathrm{p} /(\mathrm{Nov}) \\
\mathrm{kecap} / \mathrm{k} \mathrm{c} \Lambda \text { p/(Jan) }\end{array}$ & Noun \\
\hline
\end{tabular}

In the process of the acquisition of early words, the children were able to know the function of the words, and they could act as what the words meant, even though they still produced some words unclear. The analysis also showed that some of words acquired by the male and female twin children were produced correctly

From the data, the children started to communicate with adult. The children showed a significant development on words production during three months. At the beginning of the observations, the subjects could also produced some two/ multi words, although, they still used very simple words. For the last observations, it was found that the children's ability in words pronunciation had developed perfectly.
From the interviews with the parents, children acquired the language by their natural schemes and still influenced by their background and environment. It means that parents and the family should adapt their language to their children's language development without paying attention to the language structure, and the language could be understood by the children, as the parents and the family communicate with their children.

\section{REFERENCES}

Anglin, J. M. 1983. Vocabulary Development. New York: Norton.

Barret, M. D. 1995. Early Lexical Development. Oxford: Blackwell.

Citra Anggia Putri 2007. The Acquisition of Information 
Question of Two Years Old Children. Unpublished. M.Hum. Thesis. Medan: English Applied Linguistics Study Program, State University of Medan.

Clark, E.V. 1973. Aspects of Language. Cambridge: University Press

Acquisition. First Language
University Press
Cambridge:
Language and Wong. A. 2002.
Cambridge University press.
1970.Psychology and Language:
Oxford University Press.

Carey, S. \& Barlet, E. 1978. Acquiring a Single New Word. Cambridge MA: MIT Press.

de Boysson, B . B. 1999. How Language Comes to Children. Massachusetts: MIT Press.
Dale, P. S.1976. Language Development. Washington: University of Washington

Gleason, J. B. \& Ratner, N. B. 1998. Psycholinguistics. Orlando: Harcourt Brace College Publisher.

Hutabarat, H. 2007. The Acquisition of Words by 22-Month-Old Children. Unpublished. M.Hum. Thesis. Medan: English Applied Linguistics Study Program, State University of Medan.

Krashen, S. D. 1985. Principles and Practice in second Language Acquisition. Oxford. England: Pergamon press.

Lewis, M, \& Freedle, R 1972. Mother- Infant Dyad. The Cradle of Meaning. Cambridge, MA: MIT Press.

Lincoln, Y. S. \& Guba, E .G.1985. Naturalistic Inquiry. Baverly Hills: CA Sage Publications. 